\title{
NEW PERSPECTIVES ON LANGUAGE AND EDUCATION
}

Founding Editor: Viv Edwards, University of Reading, UK

Series Editors: Phan Le Ha, University of Hawaii at Manoa, USA and Joel Windle, Monash University, Australia.

Two decades of research and development in language and literacy education have yielded a broad, multidisciplinary focus. Yet education systems face constant economic and technological change, with attendant issues of identity and power, community and culture. What are the implications for language education of new 'semiotic economies' and communications technologies? Of complex blendings of cultural and linguistic diversity in communities and institutions? Of new cultural, regional and national identities and practices? The New Perspectives on Language and Education series will feature critical and interpretive, disciplinary and multidisciplinary perspectives on teaching and learning, language and literacy in new times. New proposals, particularly for edited volumes, are expected to acknowledge and include perspectives from the Global South. Contributions from scholars from the Global South will be particularly sought out and welcomed, as well as those from marginalized communities within the Global North.

All books in this series are externally peer-reviewed.

Full details of all the books in this series and of all our other publications can be found on http://www.multilingual-matters.com, or by writing to Multilingual Matters, St Nicholas House, 31-34 High Street, Bristol BS1 2AW, UK. 


\section{Sociocultural and}

\section{Power-Relational}

Dimensions of

\section{Multilingual Writing}

Recommendations for

Deindustrializing Writing

Education

Amir Kalan 
DOI https://doi.org/10.21832/KALAN7802

Library of Congress Cataloging in Publication Data

A catalog record for this book is available from the Library of Congress.

Names: Kalan, Amir, author.

Title: Sociocultural and Power-Relational Dimensions of Multilingual

Writing: Recommendations for Deindustrializing Writing Education/Amir Kalan.

Description: Bristol, UK; Blue Ridge Summit: Multilingual Matters, 2021.

| Series: New Perspectives on Language and Education: 90 | Includes

bibliographical references and index. | Summary: 'This book examines the

writing practices of three adult multilingual writers through the prism

of their writing in English as an additional language. It illustrates

some of the social, cultural and political contexts of the writers'

literacy activities and argues for a writing pedagogy that reflects the

complexity of writing as a social practice' - Provided by publisher.

Identifiers: LCCN 2020056696 | ISBN 9781788926706 (paperback) | ISBN

9781788927802 (hardback) | ISBN 9781788927819 (pdf) | ISBN 9781788927826

(epub) | ISBN 9781788927833 (kindle edition)

Subjects: LCSH: English language - Study and teaching (Higher) - Foreign

speakers. | English language - Rhetoric - Study and teaching

(Higher) - Foreign speakers. | Written communication - Study and teaching

(Higher) | Multilingualism. | Academic writing - Study and teaching

(HIgher)

Classification: LCC PE1128.A2 K35 2021 | DDC 428.0071/1 - dc23

LC record available at https://lccn.loc.gov/2020056696

British Library Cataloguing in Publication Data

A catalogue entry for this book is available from the British Library.

ISBN-13: 978-1-78892-780-2 (hbk)

ISBN-13: 978-1-78892-670-6 (pbk)

\section{Multilingual Matters}

UK: St Nicholas House, 31-34 High Street, Bristol BS1 2AW, UK.

USA: NBN, Blue Ridge Summit, PA, USA.

Website: www.multilingual-matters.com

Twitter: Multi_Ling_Mat

Facebook: https://www.facebook.com/multilingualmatters

Blog: www.channelviewpublications.wordpress.com

Copyright (C) 2021 Amir Kalan

All rights reserved. No part of this work may be reproduced in any form or by any means without permission in writing from the publisher.

The policy of Multilingual Matters/Channel View Publications is to use papers that are natural, renewable and recyclable products, made from wood grown in sustainable forests. In the manufacturing process of our books, and to further support our policy, preference is given to printers that have FSC and PEFC Chain of Custody certification. The FSC and/ or PEFC logos will appear on those books where full certification has been granted to the printer concerned.

Typeset by Riverside Publishing Solutions.

Printed and bound in the UK by the CPI Books Group Ltd.

Printed and bound in the US by NBN. 
For Sayeh and Sam 
